\title{
Philosophy and African Philosophy: A \\ Conceptual Analysis
}

\author{
Nelson Udoka Ukwamedua \\ *http://dx.doi.org// 0.43 |4/ujah.vI7i3.5
}

\section{Abstract}

Philosophy is a rational enterprise, which is predicated on culture, wonder and human experience. As a result of this, diverse persons over the yearshave participated in this noble enterprise right from its ancient origins in Egypt and Greece. Hence, it has given birth to scholars who have come into the fray to express and defend their perspective. However, one of the most pressing issues in philosophy in recent past is whether the people of Africa have philosophy i.e., whether they can express themselves like their other counterparts, in other words, is there an African philosophy? This paper in appraising this issue employed the critical analytic method in an attempt to conceptualize philosophy and then African philosophy. From this conceptualization of philosophy, it became palpable that as Africans have culture and experience which are materials for philosophy there is African philosophy; because, Africans like other rational being reflect, express and share their experiences about their world, which can and does give birth to their own philosophy.

Keywords: Philosophy, African, African Philosophy, Western Philosophy, Human Experience

\section{INTRODUCTION}

The question whether African philosophy exists was a central issue among African and western scholars from the midseventies. It was quite fashionable among these groups of people "to grin and scoff" in the words of C.B. Okolo, at the idea of such a thing as African Philosophy. Philosophy is philosophy and there can be no such a thing as "African 
Philosophy" any more than "African Mathematics' argued P.O. Bodunrin. Richard Wright arrived at the same negative conclusion from the point of view of the African people themselves, "that they are not one people or race but a diversity of races, cultures, beliefs and traditions and, consequently, in his view there could be no such a thing as African philosophy, that if at all, it would be African philosophies"."

As a result of this debate, (the great debate) it was not a surprise that the first efforts of modern African philosophers (scholars) at philosophizing on the African world and experience took on an apologetical character, establishing whether or not African philosophy existed.To give the questions any widely accepted answers however, it becomes necessary to examine briefly the nature and concepts of philosophy and then African philosophy. This is because the whole issue of the existence and non-existence of African philosophy sits on the proper understanding of what philosophy is all about.The task of this paper therefore, is to attempt a conceptual clarifications and meanings of philosophy towards an African philosophy. The essence of this basic distinction (between philosophy and African philosophy) is to introduce us to the concept African philosophy.

\section{Conceptual Clarification of Philosophy.}

The history of thought reveals that the source of most controversies in philosophy as perhaps in all other disciplines is the basic tendency of scholars either to grasp falsely or to overlook the necessary distinction. C.B. Okolo corroborates this view when he affirms that; "concepts and definitions in philosophy as in social sciences are often difficult ${ }^{\text {"iv }}$ And Kato identifies the problem in terms of semantic. Notwithstanding this problem, our approach to the concept 
of philosophy and African philosophy is neither going to be a refusal like Sidney Hook ${ }^{\mathrm{vi}}$ to even attempts a definition, nor a demonstrative one like G.E. Moore's method."vii. This paper will rather employs the thematic method in this regard, that is, in that the concept of African philosophy should first be preceded by a brief characterization of the concept, nature and scope of philosophy as a critical experience. To begin with, let us quickly point out what philosophy is not. Philosophy according to E. Ome and W. Amam, does not "connote some idea of gravity, mysticism, religion or some sort of self-imposed sanctity". viii So, it is an erroneous assumption for people to associate philosophers with seclusion, inflexibility and aloofness. Equally erroneous is to associate philosophy(ers) with cultism, mysticism, atheism and religious lukewamness. However, if the above assumptions about philosophy are erroneous, what then is philosophy? Before we attempt a definition of philosophy in its formal sense, let us see how nonprofessionals (that is, non-philosophers) understand philosophy.

\section{Misconceptions of Philosophy.}

Some Layman and even some scholars from other disciplines conceive philosophy in its loose or non-academic meaning of the term by saying that, "philosophy does connote something mystical, mysterious, difficult, esoteric, reserved for the massive intellects only. Others think of philosophy as a subject, which deals with matters out of the world, in a spiritual realm while others call philosophy people's world-view or one's moral guide". ix To understand philosophy inter alia, as one's moral guide is only but the informal meaning of philosophy often used by people or institutions as a guiding principle, that is, as a maxim, that constitutes the leit-motif or inspiring principles, which underline a people's life and action. One therefore often hear 
people saying that their philosophy of life is this or that. For instance, the motto of Nnamdi Azikiwe University is "Discipline Self Reliance and Excellence". These principles are respected by their members to protect their interest and values in order to avoid disrepute. But this by no means gives us an accurate meaning of formal philosophy as a critical discipline.

\section{Wonder as Path to Philosophy.}

Both Plato and Aristotle tell us that wonder is the beginning of philosophy. Plato echoes this in his Republic when he asserts that there is no other beginning of philosophy than this Wonder; ${ }^{x}$ and Aristotle puts it thus, "it is through wonder that men begin and originally began to philosophize". 'A contemporary and renowned scholar, Martin Heidegger, made it emphatic also that wonder does not just smark philosophy but even pervades it. In the same vein, J.O. Eneh ${ }^{\text {xii }}$ opines that philosophy of whatever culture is based on the human nature to wonder about man, his existence and destiny, as well as God and other beings in the universe. It therefore implies that wonder is at the base, that is, the first step in philosophical activity. This wonder according to C.C. Mbaegbu "... gives rise to some fundamental questions, and this is the second step. The third step is taken when man begins to reflect on these fundamental questions in search of answers". xiii This wonder that is the path to philosophy can be in the subjective, intersubjective and the objective mood. The subjective is evident in the cogito of Descartes, while the inter-subjective is vivid in the dialogues of Socrates and lastly the objective wonder was what preoccupied the Ionians and the Eleastics of the Greek Colonies of Asia Minor, Sicily and Southern Italy as they searched for the Urstoff. Now, if wonder is the root cause of philosophy, then what is philosophy? 


\section{Etymology and Definition(s) of Philosophy}

The word philosophy comes from two Greek words, Philos, Philein (love, love of, or friend of; to love) and Sophia (wisdom). Thus, to the Greeks, philosophy meant philosophia love of wisdom and a philosopher was regarded as a lover or friend of wisdom. This was what Pythagoras the one who purportedly was the first to use the word 'philosopher' called himself in preference to being called a 'wise man. ${ }^{\text {xiv }}$ Philosophy here means 'love of wisdom', not in the sense of practical (or technical) wisdom, or cleverness in dealing with the contingent isolated aspects of forces or beings, but in sense of habitual wisdom, namely, ontological knowledge of beings, their cohesion and their interactions.

Cicero in his De Officiis, defines philosophy as "rerum humanorum et divinarum causa rumque scientia" (the science of things, human and divine and of their causes). For Plato, it is an attempt to discover the ultimate, which may be knowledge. Thus, in his book Charmides, he defines philosophy as "the only science, which is the science of itself and of the other sciences as well." Understood thus, it means that philosophy is an activity of criticism and clarification. Hence, it can be exercised on any subject-matter at all; this underscores Aristotle's position that philosophy is the "science of all sciences". That is why there is philosophy of education, political philosophy, philosophy of law philosophy of science, etc. Indeed, one can say that philosophy gives reasons for all the assumptions entertained by any disciplines.

The scholastics like St. Augustine and St. Thomas Aquinas conceived philosophy as scientia rerun per ultimascausa (a rational knowledge of things through their ultimate causes). A philosopher is therefore not tied down to the immediate empirical data; instead, he transcends them by asking questions regarding their ultimate causes and principles. For Immanuel Kant, philosophy asks four 
fundamental and evergreen questions: What can I know? What I ought to do? What can I hope for? And what is man? Philosophy concerns itself with problems of knowledge of the universe, the question of social relationship, beliefs and that of self-knowledge". ${ }^{x}$ In the view of C.B. Okolo, philosophy in its academic meaning is a critical enterprise, a quest, a search or inquiry into all areas of human experience of the world. Philosophy tries to give a coherent and systematic account of the multi-faceted universe of being and knowledge. ${ }^{\text {xvi }} \mathrm{A}$ notable and foremost American contemporary pragmatic philosopher, John Dewey approaches philosophy from a functionalist perspective. He defines it as "criticism of criticisms". xvii Apart from critical functions, Dewey also gives philosophy a social function when he states, "it is a vision whose chief function is to free men's mind from prejudices and to enlarge their perception of the world around them.'

In the Blue Book, Wittgenstein states that, "philosophy, as we use the word, is a fight against the fascination which forms of expression exert upon us". In his Tractatus he defines philosophy as, "an activity that seeks logical

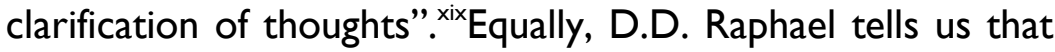
philosophers live by constant criticisms. Thus for Dewey, Wittgenstein and D.D. Raphael, criticism and clarification is the hallmark of philosophical activity. However, an American pragmatist, William James on his part observes that philosophy deals with the principles of explanation that underlies all things without exception. In him, philosophy assumes dual functions, namely, speculative and social. In its social function especially in ethical aspect, it plays a vital role in any given society, for no economy he says, "... can hope to advance where the citizens have no sense of duty, the right attitude to work and feeling of moral responsibility towards society". ${ }^{x}$ According to B. Russell, philosophy is something 
intermediate between theology and science. Like theology he continues, "it consists of speculations on matters to which no definitive knowledge has been so far ascertainable; but like science, it appeals to human reason rather than to authority whether of tradition or that of revelation. And that between, theology and science there is a no-man's land, which is philosophy". xxi

For T. Okere, philosophy is,

An effort to understand or comprehend reality as a whole, an effort to discover its meaning, an appreciation of life and eventually of culture understood as the objectivation of life $\ldots$ it is a forging from raw materials. It is a forging out of thought from the materials of culture. It is an act of intellectual creation where its new creation is a meaning born from the melting of one's total experience. ${ }^{x \times i i}$

D. Sulloan concurs with the scholastics to define philosophy as the knowledge of all things in their first principles or causes as seen by the natural light of reason. In the same vein, Karl Jasper defines philosophy as a critical and reflective thinking. He therefore holds that philosophy is "thinkification"xxiii, and like Professor Anthony Flew would say it is, "thinking upon thinking" or thinking upon thought. Moreover, C.E.M. Joad, defines philosophy as the clearing house to which the result of all other human inquiries are brought and in which the records of all forms of human experience are sifted assessed and evaluated. From the above definition, it becomes obvious that philosophy does not enjoy a univocal definition. This is because on one hand it is a concept hence, it tends to elude every definition, and on the other hand, experts in this discipline have offered diversified definitions. However, despite the seemingly lack of consensus among professional philosophers with regard to the meaning of philosophy as an academic discipline, many if not most philosophers would view it as a special form of rational and 
critical activity that relies most on wonder and experience of reality. They saw it also as a personal reflection on reality and what it means for man. In this general task, philosophy subjects unorganized, uncritical mass of beliefs and unfounded view about nature and human experience to a rational scrutiny to find out if there are rational grounds for maintaining these views. By engaging in this type of critical and rational inquiry, a philosopher indeed becomes a true and real lover of wisdom.

\section{Concept and Definition of African Philosophy}

Just as in philosophy, the concept of Africa has eluded the thorough grasp of both African, western and Asian scholars that many interpretations and definitions of the concept abound. However, in this paper, the word Africa(n) is understood to be the geo-political and socio-cultural entityenglobed by the continent of Africa: North, Middle and South. It likewise includes the old Afro-Islamic Egypt ${ }^{\text {xxiv }}$, Subsahara black central as well as white South Africa. Those also included in the definition of Africa are the historically Africanoriginated, Afro-American and Afro-Asian peoples whose roots are African. Though they no longer reside in the continent but they are tied by history and origins to Africa just like the President of the United States of America (USA), Barrack Hussein Obama whose root is Kenya in East Africa. Others who are involved and that can do African philosophy are those who, though not African by geographical delineation have resided in the continent for a very long time (or even nationalized and/or married in the continent) and are sufficiently and reasonable informed, versed and interested in reflecting on the African mystery just as non westerner scholars reflect on western reality.

Having finished the working definition of Africa, it is quite unfortunate to state here that the earliest studies and 
writings on African philosophy and religion were carried out by Europeans and American missionaries, anthropologists, sociologists etc who were rather motivated by their quest to justify existing racists and colonial structure than for scholarship. With their Eurocentric ${ }^{x \times v}$ mentality they sought to establish that Africa was such a physically and spiritually dark world that nothing good could reside in it or come out of $i^{x \times v i}$. These supercilious Eurocentric scholars conceived philosophy as preserved for the higher breed of humanity. Oguah even observes that the very concept of African philosophy is apt to cause scornful or at least skeptical laughter in certain quarters in the West; they even went ahead to say that as far as the east is from the west, so far is Africa removed from philosophy. ${ }^{\text {xvii }}$ In the wake of this Eurocentric tendency, some African scholars schooled in the Aristotelian and Cartesian tradition even joined the wave of the Eurocentrists to question the reality of African philosophy. Bodunrin ${ }^{\text {xviii }}$ even dejected the works of John Mbiti, Kagame Alexis etc., as collective thought and does not qualify as philosophy. Paulin Hountounji denies African any philosophy prior to the emergence of modern science and went ahead to condemn the works of Marcel Griaule, Senghor and a host of others as nothing but African tradition and orature; as he went further to question the authorship of Tempels ${ }^{\text {xxix }}$. For him, the works of Julius Nyerere, Kwame Nkrumah and Leopold Senghor are but a search for cultural identity and must not be confused as philosophy. ${ }^{x \times x}$ On his part, Odera Oruka jested as the idea of African philosophy as superstition, mythology and avows like Levy Bruhl that the western paradigm is the yardstick. Robin Horton's ${ }^{x \times x i}$ own aversion for the existence of African philosophy stems from the fact that it lacks formal logic/criticality and epistemology. Henri Maurier ${ }^{x \times x i i}$ also defended the view that formal 
philosophy as espoused by the West is not yet in existence in Africa.

However, there are also some contenders who provided detailed and critical responses to the phony ideas of these Eurocentric scholars. OlabiyiYai in his article 'theory and practice of philosophy: the poverty of speculative philosophy' objected to the insistence of western paradigm for the assessment of Africa philosophy and said that it smacks of European ethno-centricism. ${ }^{\text {xxiii Masolo contends }}$ that in the face of cultural distortion, political and economic intimidation, 'black people wanted to reaffirm their culture, derogated and nearly destroyed by westernism, slavery and colonialism. The black race had to heed to a re-affirming and re-proclamation of itself ${ }^{\text {xxiv }}$.

With Francis Njoku, I think that the treatment of African continent by the traditional discipline put African philosophy in a defensive position. It has to defend its very existence, a defense that was not required from European, Asian or Indian philosophy. Hence there is a politics as to the status of African philosophy, which implies a debate about the different conceptions of philosophy and glumly 'the political dimension of the debate becomes inescapable. ${ }^{x x v}$ In the wake of the above I will like to amplify the remarks of Imbo concerning African philosophy that, "the indigenous cosmologies, the traditional beliefs such as those about supernatural beings and magic. Beliefs, myths and cosmology are believed to be interwoven into the complex ritual practices that are the manifestations of philosophy. Unwritten and unsystematised, the rituals and systems of belief nevertheless form an intricate web that guides the people in making sense of their lives". ${ }^{\text {xxviso }}$ to deny African people philosophical thought is to imply that they are unable to reflect or to conceptualize their experience, even as the African proverbs are the undeniable result of reflection on 
their experience in the world. According to Gyekye, African thought, if it is thought at all, encompasses philosophy ${ }^{x \times x v i i}$. With these few critical response to the clumsy ideas of the Eurocentric scholars, the existence of African philosophy should be taken for granted and we move on to do African philosophy as Joseph Omoregbe had admonished.

Philosophy raises critical questions about the universe and in the phrase of Heidegger, "... on man himself and on the meaning and goal of human being-there". xxxviii'African philosophy on the other hand articulates and critically reflects on the total experience of the African, on how African sperceive reality and reacts to their experiences and immediate environment. African philosophy thus places special emphasis on the African, his world, history, values, and the like, and on the significance that these have for him. In general, African philosophy explores particularly how the Africans experiences, conceives and interprets nature, society, religion, man, God, human conduct, and lots more. In short, it deals with the African in his radical subjectivity, that is, precisely as an African. According to Pantaleonlroegbu, ${ }^{\text {xxxix }}$ African philosophy is the reflective inquiry into the marvels and problematics that confront one in the African world, in view of producing systematic explanation and sustained response to them. It is an enquiry into two aspects: philosophical and African. As philosophy, it is a philo-sophia, a quest for (African) wisdom. The reflective and systematic investigation into the fundamental questions confronts the human beings in Africa. These questions border on reality as a whole: empirical and meta-empirical. The questions concern the universe, humanity, the neighbour, the self, life and supernatural beings: God, the spirit and the after-life. This is as a result of the fact that in line with Aristotle there is a natural quest in man to discover the inner reality of things both in themselves and as they confront him. Interestingly, 
this quest is a universal phenomenon as it is found in all cultures, in various manners and at all times and the African as part of humanity confidently and genuinely participates in this search for meaning and coherence.

As African, Africans as noted above are bonifide members of humanity and as such have continued in their quest to provide answers to the fundamental questions that confront them in their world. The responses are and can be expressed in myths, symbols, cultural and linguistics institutions, in verbal depositum and recently in writing. It is also good to note that what makes African philosophy is not the manner of the expression of African thought nor in the persons involved but rather in the content and nature of the thought itself and in its method of enquiry employed.

Therefore, following Kant's assertion that philosophy asks for fundamental questions, namely, What can I know? What ought I do?, What can I hope? and What is man?, African philosophy also rises these questions. African philosophy thus, seeks to understand the African person. It systematically and coherently articulates his experience of reality. Its specific area and material object is therefore primarily and directly the African and his world. Therefore, briefly defined, African philosophy is a critical thinking on the African and his experience of reality. In the words of C. B. Okolo it is, "a path to a systematic, coherent discovery and disclosure of the African as a being-in-the African world and disclosure of himself and his world by critical reflection, the African grasps reality, that is to say, attains the truth about man and the cosmos in its entirety". ${ }^{\circ}$ As a creative and rational inquiry, African philosophy seeks to understand, clarify, and explain every aspect of African experience. As a particular system on its own right, African philosophy explores the various ways that the African experiences and interprets nature and all reality as a being in-the-African 
world. Along this same line, K.C. Anyanwu defines African philosophy as that "which concerns itself with the way in which African peoples of past and present make sense of their existence, of their destiny and of the world in which they live". xii

\section{Concluding Reflections}

Philosophy as a specialized human activity is something natural to man. Just as Aristotle rightly observed, 'man by nature wants to know'. Therefore, to philosophize is akin to human nature; such that its origin, according to Hyland "... is human nature itself, because philosophy is the culmination, the highest of what it is to be human". "lii"However, philosophy in its academic sense, that is, as a conscious critical reflection of human experience is not engaged by everyone. For, although man is by nature a philosopher, not all men reflect always at a philosophic level. Hence, methodic philosophy in its academic meaning is not coeval with man. Philosophy is not something out there, or "something already made". philosophy is a creative enterprise of a reflecting people, who have attained a certain level of literacy. So, philosophy in its academic meaning is according to Okolo, "a second order activity, , fliv for it emerged at a certain stage in the development of human society when man thought had attained a high level and had a favourable social conditions for it.

Aristotle himself ascertain that man began to philosophize only when almost all the necessities of life and the things that make for comfort and recreation had been secured. Also, mention can be made in this regard to John Dewey in his explicit view that philosophy starts from some deep and wide way of responding to difficulties life presents, but it (that is, formal philosophy) grows only when material is 
at hand for making this practical response conscious, articulate and communicable. The strong conclusion one can draw from these views is that in the academic meaning of the word, philosophy emerges in time and develops with leisure and intellectual maturity. For John Newman "it is the education which gives man a clear and conscious view of his own opinions and judgment ... a truth in developing them, an eloquence in expressing them and a force in urging them".

Thus, all philosophies are not at the same level of selfdevelopment and since different peoples in different cultures attain different levels of growth in culture, intellectual maturity, leisure, education, and so on, they equally attain different levels of philosophical speculation and sophistication. But, the ability of rational discourse and consequently of philosophizing is innate in all peoples of all places and of all time. In the same vein, African philosophy in its academic meaning is a rational critical inquiry essentially on the African and his world, which has now become prevalent among African Scholars. For, among preliterate Africans for instance, their understanding and articulation of their experience were largely uncritical, uncoordinated and undifferentiated. It was generally through myths, idioms, religious arts and symbols. But in modern times, with the emergence and increase in formal education, critical reason and training, reflections have steadily come alive among educated Africans. And this underscores the fact that nobody has categorically said that there cannot be an African philosophy.

Though a scholar like Odera Oruka among others contend that what enthno-philosophers like J.S. Mbiti, Placide Tempels, Alex Kagame and others parade as philosophy is philosophy only in the loose sense of it (debaed sense), that they only stand as raw materials for formal and academic philosophy after the necessary tools have been employed to

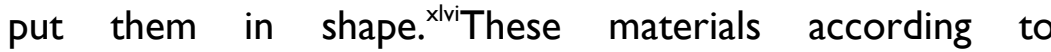


Okere ${ }^{x v i i}$ can serve as a philosophemena that is, as a raw material for philosophizing. For since nobody, according to

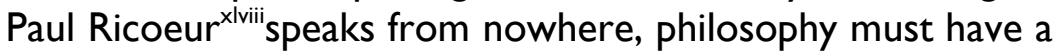
base or foundation, and culture is the foundation philosophy. Thus, through critical, rational, systematic and coherent approach, or in the words of Okere a hermeneutical approach to culture, one "chisels" out philosophy. The position of Okere and Odera Orukadraws one's attention to Pantaleonlroegbu's distinction between folk philosophy discoverable in all cultures and traditions and scientific philosophy. However, it is paramount to take cognizance of the fact that even the so-called folk-philosophy has in its internals, some basic logic and rationality, method and functionality, rigour and coherence. And as a matter of fact, the difference between it and the so-called scientific philosophy appears to be a matter of degree, not fact of rationality, systematicity and method. After all, rational or scientific philosophy is in itself also a product of culture i.e., a culture philosophy; a good example is the origin of western philosophy among the Greeks in cosmology/cosmogony and mysticism/religion. And this same folk-philosophy is a rational thought of some persons appropriated by the community. Most of the philosophers in the western tradition postulated their theories based on their immediate experience, culture and environment so philosophy is a culture philosophy and if that is the case, the culture of Africans is the root-foundation of their philosophy so there is an African philosophy. This amplifies the point of view of Samuel Imbo that unwritten and unsystematised, the rituals and systems of belief nevertheless form an intricate web that guides the people in making sense of their lives and according to Kwame Gyekye, African thought, if it is thought at all, encompasses philosophy. 


\section{Nelson Udoka Ukwamedua \\ Department of Philosophy \\ Veritas University, Bwari, Nigeria}

\section{Endnotes}

i C. B. Okolo, African Philosophy, (Enugu: Cecta Pub., 1992), p.14.

ii P. O. Bodunrin, "The Question of African Philosophy", (ed.) C.S. Momoh, The Substance of African Philosophy, (Auchi: African Philosophy Projects' Pubs., 1989), p. 23.

iii Richard Wright (ed.), African Philosophy: An Introduction, (Washington D.C. University of

America Press, 1977).

C.B. Okolo, African Social and Political Philosophy: Selected Essays, (Nsukka: Fulladu Publishing Company, 1993), p. 6.

v Byang H. Kato, Theological Pitfalls in African, (Kenya: Evangel Publishing House, 1975), p. I

vi Sydney Hook declined to give any formal definition of philosophy on the ground that any formal definition presupposes some conception unlikely to be shared by all philosophers. (C.f., Sydney Hook, "The Uses of Philosophy", in The Range of all Philosophy, Introductory Readings, (ed.) Harold H. Titus and Maylon H. Hepp, (New York: Van Nostrad Reinhold Company, 1970), pp.1 - 2.

vii G.E. Moore, when asked by his students to define philosophy was reputed to have pointed at the great works of famous philosophers in library and said in reply, when you have mastered what is in those works, then you know what philosophy is all about.

viii E. Ome and W. Aman, Philosophy and Logic for Everybody, (Enugu: Institute for Development Studies, 2004), p. 2. 
ix C. B. Okolo, Philosophy of Education and Education of Philosophy, (Enugu: Snapp Press Ltd. 1989), p.19.

x P.O. Bodunrin (ed.), Philosophy in African Trends and Perspectives, (IIe-Ife: University o Ife Press Ltd., 1985), p.16.

xi Aristotle, Metaphysics, 98 2b 10.

xii J.O. Eneh, Philosophy and Logic for Beginners, (Enugu: Snaap Press Ltd., 2001), p.11.

xiii C.C. Mbaegbu, "The Concept of Philosophy" in Ogirisi: A New Journal of African Studies Vol. 2, No. 1(June 2004), pp. 1 - 13.

xiv T.U. Nwala, Igbo Philosophy, (Lagos: Literamed Pubs., (Nig. Ltd., 1985), p.1.

Immanuel Kant, Groundwork to the Metaphysics of Morals, Trans. With Commentary by Paton, (London: Hutchinson University Library, 1948), p. 8.

C. B. Okolo, Problems of African Philosophy and one other Essay, (Enugu: Cecta (Nig) Ltd., 952), pp. 9 - 10. John Dewey, Experience and Nature, (New York: Dover Publication, Inc. 1958), p. 398.

xviii John Dewey, Reconstruction in Philosophy, (New York: Beacon Press, 1957), p. 53.

xix Ludwig Wittgenstein, Tractaus Logic-Philosophicus, (Londong: Routeledge and Kegan Paul, 1961), 6: 53.

William James, APluralisic Universe, (New York: 1909), p. 314.

xxi B. Russell, History of Western Philosophy, (London: Unwin, 1871), p. 7.

xxii T. Okere, African Philosophy: A HistoricoHrmeneutical Investigation on the Conditions for its Possibility, (New York: University Press of America, Inc., 1983), p. xiv.

xxiii Karl Jasper, Philosophy in the Existentialist Tradition, (ed.) NimoLanguilli, (New York: Double day, 1997), p.173. 
xxiv During the period of the 'great debate', many have come to recognize the sinister move and plot to baptize North Africa including Egypt, as Oriental because of the advantages for western science, culture and development. Today, Egypt is fully considered African from all perspectives as calls have been made by many for the stolen legacy of African to be restored. For details see, Chiek Anta Diop, The African Origin of Civilization, (New York: 1974); Keita L., "The African Philosophical Tradition:, in Wright R. A., (ed.), African Philosophy, (New York: UPA 1984), pp. 59ff; Innocent Onyewuenyi, The African Origin of Greek Philosophy: An Exercise in Afrocentricism, ( Nsukka: University if Nigeria Press, 1993), particularly see, pp. $56-74$. George James, Stolen Legacy. And others scholars.

xxv Eurocentric refers to the psychological and philosophical framework which projects European, White - Caucasian people, their history, culture, philosophy, values etc as the center of the universe on which all else depend and around which all else evolve. PieroGheddo calls this rational anomaly a 'mania'.

xxvi Bolajildowu, African Traditional Religion: A Definition, (London: S C M, 1973), p. 86.

xxvii Benjamin Oguah "African and Western Philosophy: A Comparative Study", in (ed.) Richard Wright African Philosophy (New York: 1984), p. 213.

xxvii Peter Bodunrin "The Question of African Philosophy", in Richard Wright (ed.) African Philosophy (New York: 1984), p. 11.

xxix PaulinHountondji, African Philosophy: Myth and Reality (London: Hutchinson University Library for Africa, 1983), cf. pp. 55 - 70.

xxx Ibid. p. 60.

xxxi See, Robin Horton and A. Finnnegan (ed.), Modes of Thought, (New York: 1974). 
xxxii Francis O. C. Njoku, Essays in African Philosophy, Thought \& Theology, (Owerri: Clacom Communications, 2002), p. 10. For more details See, Henri Maurier, "Do We Have an African Philosophy? In Richard Wright (ed.), African Philosophy (New York: 1984).

xxxiii OlabiyiYai "Theory and Practice of Philosophy: The Poverty of Speculative Philosophy" (1977) as quoted by Francis O. C. Njoku, Essays in African Philosophy, Thought \& Theology, (Enugu: Snapp Press Ltd, 2002), p. 10.

xxxiv Masolo D. O. African Philosophy in Search of Identity, (Indianopolis: Indiana University Press, 1994), p. 3.

xxxv Francis O. C. Njoku, Essays in African Philosophy, Thought \& Theology, (Enugu: Snapp Press Ltd, 2002), p. 10.

xxxvi Samuel OluochImbo, An Introduction to African Philosophy, (Maryland: Rowman Littlefield Publishers, Inc., 1998), p. 55.

xxxvii Kwame Gyekye, An Essay on African Philosophical Thought (New York: Cambridge University Press, 1987), p. 8.

xxxviii M. Heidegger, An Introduction to Metaphsics Trans. Ralph Manheim, (New York: Anchor Books Double Day, 1961), p. 8.

xxxix PantaleonIroegbu, Enwisdomization and African Philosophy, (Two selected Eassays), (Owerri: International Universities Press Ltd., 1994), pp. 116 117.

xl C. B. Okolo, What is Philosophy, (Enugu: Cect Pub., 1992), p. 4.

xli K.C. Anyanwu and E.A. Ruch, African Philosophy: An Introduction, (Rome: Catholic Book Agency, 1981), p.17. 
xlii A. Hyland, The Origins of Philosophy. Its Rise in Myth and the Pre-socrates, (New York: Caapricorn Books, G.P. Putnam's Sons, 1973), pp.26 - 27.

xliii A.P. Sheptulin, Marxist-Leninist Philosophy, (Mosco: Progress Publishers, 1978), p. 31.

xliv C.B. Okolo, "African Philosophy: A Process of Interpretation", in Africana Marburgensia, Vol. 15, No. 2, (1983), p. 88

xlv J.H. Newman, The Scope and Nature of University Education, (London: 1915), p. 171.

xlvi Odera Oruka, "Four Trends in African Philosophy", Paper presented at the William Amo Symposium in Accra Ghana, (July 1978), pp. 24 - 29.

xlvii T. Okere, African Philosophy.

xlviii P. Ricoeur, "Symbolism and Evil", trans. T. B. De Ford, in Union Seminary Quarterly, Vol. 27 No. 3, (1973), p. 352. 